
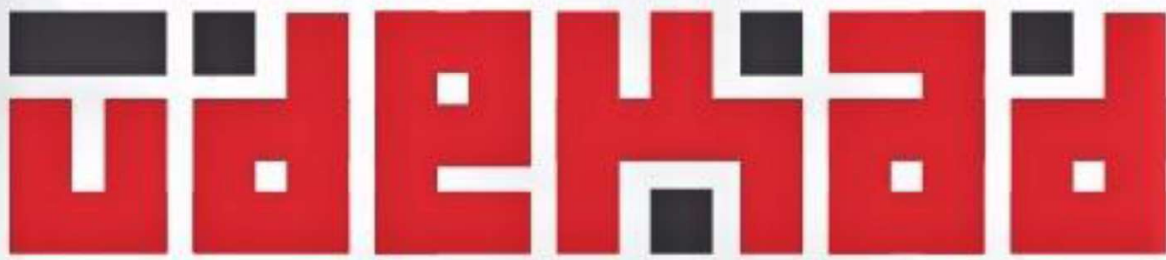

INTERNATIONAL JOURNAL OF LANGUAGE, LITERATURE AND CULTURE RESEARCHES

МЕЖДУНАРОДНЫЙ ЖУРНАЛ ЛИНГВИСТИЧЕСКИХ, ЛИТЕРАТУРОВЕПЧЕСКИХ И КУЛЬТУРОЛОГИЧЕСКИХ ИССЛЕПОВАНИЙ

Vol: 2, Issue: 1, 2019

Sayfa-Page:1-10

E-ISSN: 2667-4262

\title{
ТӘУЕЛСІЗДІК ЖЫЛДАРЫНДА ЖАРЫҚ КӨРГЕН КӨРКЕМ ШЫҒАРМАЛАР ТІЛІНДЕ КЕЗДЕСЕТІН ДИАЛЕКТІЛЕР
}

\author{
DIALECT IN THE LANGUAGE OF FICTION PUBLISHED DURING INDEPENDENCE
}

\section{Galiya TOKTIMANOVA*}

\begin{tabular}{|c|c|}
\hline Мақала туралы ақпарат & АННОТАЦИЯ \\
\hline $\begin{array}{l}\text { Geliş: } \\
\text { Kabul: }\end{array}$ & \multirow{3}{*}{$\begin{array}{l}\text { Мақалаға арқау болып отырған мәселе тәуелсіздік жылдары аралығындағы шығармалар } \\
\text { бойынша көркем әдебиет мәтіндеріндегі диалектілік ерекшеліктер. Көркем мәтіндердегі } \\
\text { жергілікті сипатқа ие ерекшеліктер жалпы халықтық лексиканың құрамдас бөлігі ретінде } \\
\text { танылып, халқымыздың мол рухани байлығының бір саласы ретінде қарастырылуы керек. } \\
\text { Аталған жылдар аралығындағы көркем мәтіндердегі диалектизмдерді жеке алып зерттеу } \\
\text { - қазақ тіл білімінің жалпы диалектология саласы үшін және әдеби тілдің кемелденуі мен } \\
\text { толығуы үшін диалектизмдердің әсері, сондай-ақ лингвомәдениеттаным және } \\
\text { этнолингвистика саласы үшін де маңызы зор. Көркем шығарма тілі әдеби тілге қарағанда } \\
\text { аумақты, себебі онда диалектизмдер де, ауызекі тіл үлгілері де, авторға тән қолданыс та } \\
\text { кездеседі. Көркем шығармада жазушы суреттеп отырған объектісін жан-жақты таныту } \\
\text { үшін, ұлттық тілдің барлық мүмкіндігін пайдаланады, бірақ оның да өз орны болуы керек. } \\
\text { Ендеше әдеби тіл нормасын, тіл мәдениетін қалыптастыруға көркем шығарма өзіндік } \\
\text { рөль атқарады. Екінші жағынан көркем шығарма тілі әдеби тілдің нормасына лайық } \\
\text { сөздерді қосып отырады. Бұл көркем шығарма тілі деген мәселенің тілдің өзекті } \\
\text { мәселелерімен бірге жасайтындығын көрсетеді. Сондықтан көркем шығармаларда } \\
\text { диалектизмдерді қолдану мәселесін зерттеу тіл білімі үшін өзекті. Осы мақсатта мақалада } \\
\text { тәуелсіздік жылдарында жарық көрген көркем шығармалар тілінде кездесетін } \\
\text { диалектизмдердің стилистикалық қызметі, жергілікті ерекшеліктерді қолданудың } \\
\text { стильдікмақсаты, диалектизмдер, олардың сипаты, қолданысы талданады. }\end{array}$} \\
\hline $\begin{array}{l}\text { Кілт сөздер: } \\
\text { Қазақ тіл білімі, } \\
\text { Диалектология, } \\
\text { Диалектілер, } \\
\text { Этнографизимдер, } \\
\text { Әдебиет. }\end{array}$ & \\
\hline Araştırma Makalesi & \\
\hline
\end{tabular}

晜 Received: 11.19 .2018

The topic of this article is the dialectical features of independence work in the texts of fiction. Local features in artistic texts should be recognized as an integral part of the general public dictionary and considered one of the moral wealth of our people. Individual

Accepted: 01.15.2019 work on the dialectic in literary texts over years is important for the impact of literacy on linguistics and ethnology; as well, the general dialect of Kazakh linguistics, and the dialectic of literary language. Creative art is much more common than literary language because it includes both the dialectical and verbal language; as well, the unique use of the author. In art, the author uses all abilities of the national language to make the object widely visible, but its place must also be present. Therefore, artistic work plays a role in the formation of the literary language norms and language culture. On the other hand, the art of creation adds meaning to the norm of the literary language. Together with the language of art, it shows a language with real language problems. Therefore, the study of the dialectical use of art is related to linguistics. For this purpose, this article analyzes dialectic style, local characteristics, dialecticism, characters and the use of language in artistic works published in years of independence.

Keywords:

Kazakh linguistics,

Dialectology,

Dialects,

Ethnographies,

Literature.

Research Article

* Öğr. Gör., Kazak-Rus Tıp Üniversitesi, Almatı / KAZAKISTAN, E-mail: g.toktyman@gmail.com

ORCID (D) https://orcid.org/ 0000-0002-2806-9953

Bu makaleyi şu şekilde kaynak gösterebilirsiniz (APA):

Toktımanova, Galiya (2019). "Тәуелсіздік Жылдарында Жарық Көрген Көркем Шығармалар Тілінде Кездесетін

Диалектілер". Uluslararası Dil, Edebiyat ve Kültür Araştırmaları Dergisi (UDEKAD), 2 (1): 1-10. 


\section{Extended Abstract}

A literary text is a single world that shapes national unity, psychology, outlook, life experience, traditions and beliefs. A literary text is a linguistic image and a mirror of the national culture, that is why it is possible to get the material and spiritual culture of a certain nation in a work of art, to know its linguistic basis. There is a problem of using local features in a work of art. There is no equal sign between the language of a work of art and the concept of a literary language. Language of fiction is the most widely used place to show the richness of national language.

This article discusses the dialectical features in the texts of fiction literature on works over the years of independence. The peculiarities of local character in literary texts should be recognized as an integral part of the general cultural vocabulary and considered as the sphere of moral wealth of the people. Separate study of dialectics in literary texts during these years is of great importance for the sphere of General dialectology of Kazakh linguistics and the influence of dialect on the development and replenishment of the literary language; as well, in the field of cultural linguistics and ethno linguistics.

The language of the work of art is more extensive than the literary one, as it contains both dialectics and oral linguistic images, and the use characteristic of the author. In a work of art, the writer uses all the possibilities of the national language in order to diversify the described object, but they must also have their place. Thus, a work of art plays a role in the formation of the norms of the literary language, language culture. On the other hand, the language of the work of art adds words that correspond to the norms of the literary language. This indicates that the problem of the language of a work of art takes place in the actual problems of language. Therefore, studying of use of dialectics in works of art is relevant for linguistics.

The study of dialectical features in our language has a great importance. The remaining of an ancient tribal language is one of the important dialectical features, preserved as remnants of an ancient language. It includes borrowed words associated with communication of the Kazakh people with neighboring nations in different areas. Recently, there are also new language elements in the language of young writers, which arose under the Soviet power and became the basis for the study, i.e. residents of independent Kazakhstan, who gained sovereignty. All this research is considered in the theoretical part of the Kazakh dialectology, and the use of language features, that is, dialects in the language, the correct use and ability to analyze is the result of theoretical knowledge.

The purpose of studying the scope of dialect words in works of art is to teach the student the purity of language, expressive speech and artistic, linguistic skill. Future teacher has to correspond with this in order to prepare the student. Moreover, purity of language is a guarantee of transparency of a thought. From this practical point of view, teachers need to know dialect words and navigate in their history.

The various language features, the phenomena found in texts of fiction, are gained from national language. The language of fiction is an indicator of vocabulary models and vocabulary development. When writing a literary work, the writer uses every word, sorting and choosing it. The language of fiction is the initiator that forms the norms of the literary language.

To this end, the article analyzes the stylistic activity of dialecticisms encountered in the language of works of art published during the years of independence, the stylistic purpose of the application of local features, dialectics, their nature and application.

In addition, this study will reflect the attitude of local features to the language of works of art, the nature of local features of the Kazakh language, goals, ways and principles of using dialecticism in the work of art, as reviewed by the works, reviews of scientists and researchers. The stylistic activity of dialectics in the works of modern writers, the stylistic purpose of applying local peculiarities, dialectics, their character and application, semantic groups are considered setting out the works and substantiating examples. 


\section{BAĞIMSIZLIK YILLARINDA YAYIMLANAN YAZILI ESERLERDEKI LEHÇELER}

\section{Özet}

Makalenin konusu, kurgu metinlerinin bağımsızlık eserlerinde diyalektik özellikleridir. Sanatsal metinlerdeki yerel özellikler, genel halk sözlüğünün ayrılmaz bir parçası olarak tanınmalı ve halkımızın bol manevi zenginliklerinden biri olarak kabul edilmelidir. Yıllar boyunca edebi metinlerdeki diyalektikle ilgili bireysel çalışma, Kazak dil biliminin genel lehçesi ve diyalektiği, edebi dilin mükemmelleşmesi ve okuryazarlığı için olduğu kadar, dilbilim ve etnolojibilim etkisi için de önemlidir. Yaratıcı çalışma sanatı edebi dilden çok daha yaygındır, çünkü hem diyalektiği hem de konuşulan dili ve ayrıca yazarın kendine özgü kullanımını içerir. Sanat eserinde, yazar nesneyi geniş ölçüde görünür kılmak için ulusal dilin tüm yeteneklerini kullanır, ancak onun yeri de olmalıdır. Bu yüzden sanatsal çalışma, edebi dil normlarının, dil kültürünün oluşumunda rol oynar. Öte yandan, yaratma sanatı edebi dil normuna anlam katmaktadır. Bu, sanat dilinin yanı sıra bir dili gerçek dil problemleriyle birlikte gösterir. Bu nedenle, sanat eserlerinde diyalektik kullanımının incelenmesi dil bilimi ile ilgilidir. Bu amaçla çalışma, bağımsızlık yıllarında yayınlanan sanatsal eserlerinin diyalektiğin üslup etkinliğini, yerel özelliklerin kullanım şeklini, diyalektizmi, karakterlerini ve bağımsızlık yıllarında yayınlanan sanatsal eserlerin dilinde kullanımlarını analiz etmektedir.

Anahtar Kelimeler: Kazak dil bilimi; diyalektoloji; lehçeler; etnografya; edebiyat.

Ұлт айнасы тіл десек, тіл - халқымыздың тұрмыс тіршілігінің, ой-сезімінің, елдігі мен ерлігінің, болмысының, дүниетанымы мен парасатының куәсі. Өркениетті қоғамда тіл адамзаттың баға жетпес құндылығы. Ал осы тілдің сөз байлығын танытатын көркем әдебиет.

Біріншіден, бұл өзі - тарихи категория. Сондықтан да жалпыхалықтық тілдің тарихы мен қалыптасуын, оларды лексика-фразеологиялық, грамматикалық жағынан тексеру мәселелерінде диалектілердің көп пайдасы бар. Екіншіден, мұны әдеби тілді байытудың бір көзі деп қарау керек. Кейбір жаңа ұғымдарды, заттарды немесе бұйымдарды қазақша атау керек болғанда және баламасы әдеби тілден табылмаған жағдайда оларды осы жергілікті ерекшеліктерден іздеген абзал. Диалектизмдерден алынатын, кәдеге асырылатын сөздер әлі де бар» - дейді ғалым Н.Уәлиев (Уәлиев 2007: 26).

Тілдің әркелкі түрлері: онда әдеби тіл және жергілікті тіл ерекшеліктері (диалектілер), ауызекі тіл және арго (толық емес, редуцирленген - сөздік деңгейіне дейін қысқартылған тілдік жүйе) бар екендігі белгілі.

Прозалық шығармаларда диалектілік ерекшеліктер негізінен кейіпкерлердің тілінде қолданылады. Сонымен қатар, кейде автор сөзінде қолданылуы да орын алып отырады. Жазушылар диалектілік ерекшеліктерді көбінесе жергілікті тұрғындарды сипаттауда, халық тұрмысын шынайы көрсету, белгілі бір аймаққа тән материалдық және рухани мәдениет ерекшеліктерін беру үшін, халықтың болмысын, рухын шынайы түрде бейнелеу мақсатында қолданады.

Жергілікті ерекшеліктердің лирикалық поэзияда қолданылуы мен прозалық шығармаларда қолданылуының өзіндік ерекшеліктері бар (Сыздық 2005:133). Экспрессивті қызметі автордың жеке өзі таратып отырған хабардағы көріністермен байланысты, ендеше сөз өз тұлғасын білдіре алудың құралы ретінде қызмет етеді. 
Импрессивті қызмет сөйлеушінің жеткізгелі отырған хабарына қаратыла айтылады десек, ол сөйлеушінің әсеріне байланысты адресат хабардың қандай тілмен жеткізілгені туралы ақпаратты алумен қатар, автордың осы хабарға деген эмоционалдық жай-күйін біле алады. Бұл қызмет белгілі бір әрекеттерге байланысты адресаттың көңіл-күйіне, сезіміне, талап-тілегіне ықпал жасай алады.

Прозалық шығармалармен салыстырғанда, лирикалық шығармаларда диалектілік ерекшеліктер әлдеқайда аз қолданылады, оның үстіне онда негізінен лексикалық ерекшеліктер, ал фонетикалық, грамматикалық ерекшеліктер мейлінше аз. Бұл жерде жергілікті тұрғындардың тіліндегі фонетикалық, грамматикалық ерекшеліктерді көрсету емес, ойын нақты беру, қысқа да түсінікті етіп жеткізу мақсатынан туындаған.

Лексикалық ерекшеліктер өз ішінен бірнеше топтарға жіктеледі. Атап айтқанда:

1) н нақты лексикалық ерекшеліктер - әдеби тілде баламасы, синонимі бар сөздер;

2) семантикалық ерекшеліктер - белгілі бір тұрғындардың тілінде жалпыхалықтық қолданыстан бөлек мағынасы бар сөздер;

3) этнографиялық ерекшеліктер - белгілі бір аймаққа ғана тән, басқа жерлерде қолданылмайтын немесе олардан түбегейлі ерекшеленетін заттар мен құбылыстардың аттары.

Этнографизмдердің жалпыхалықтық тілде баламасы болмайтындықтан, оларды сипаттама түрінде ғана беруге болады;

Фразеологиялық ерекшеліктер - белгілі бір аймаққа ғана тән, сол жерде ғана түсінікті болатын тұрақты сөз тіркестері (Сыздық 2005:145-146).

Жазушы тілін, сөз қолдану ерекшеліктерін сөз еткенде, ең алдымен, екі факті: а) белгілі бір сөздерді қолдануда автордың өзіндік позициясын, мақсатын түсіндіру; ә) автор бейнесінің ерекшеліктеріне мән беру.

Ақын-жазушылардың шығармаларында кейіпкер тілінде (кейде лирикалық кейіпкер автормен астасып, орайласып жатады) жергілікті тіл ерекшеліктерінің кеңінен қолданылуы - шығарманың құндылығын арттырады.

Дегенмен қаламгер тілінде жергілікті ерекшеліктерді қолдануында екі түрлі басты кемшілік байқалады: а) жергілікті ерекшеліктерді автордың өз баяндауында (автор мен лирикалық кейіпкер сәйкес келмеген жағдайда) қолдануы; ә) сол өңірге жат, таныс емес, басқа аймақта қолданылатын сөздерді қолдануы, яғни, автор жергілікті тіл ерекшеліктерін қолданғанмен, оның қай аймаққа тән екендігінен туындайтын фактор, себебі лексикалық ерекшеліктер зерттеушілер назарын ертеден-ақ өздеріне аударған, бір тілде сөйлейтін екі адам өз ара түсініскенмен, жекелеген сөздерді білмеуі немесе қолданбауы, екінші жағынан, сол сөзге тілдік жағынан назар аудартады.

Фонетикалық, грамматикалық ерекшеліктер сөйлеуші тіліндегі кейбір ерекшеліктерді байқауға мүмкіндік береді, бірақ өзара түсінуге елеулі-ықпал ете алмайды. Ал лексикалық ерекшеліктерді жекелеген дыбыс, фонема, қос морфема 
көлемінде емес, тұтас лексикалық бірлік болғандықтан, адресанттың ойын түсінуде олар маңызды қызмет атқарады (Сарыбаев, Қалиев 2004: 25).

Прозалық шығармаларда лирикалық шығармалармен салыстырғанда диалектілік қолданыстар өте көп кездеседі. Диалектілік қолданыстар көбінесе автордың тілдік санасында қалыптасқан ұғым ретінде немесе авторлық позицияны анықтау үшін және кейіпкер болмысын ашу мақсатында қолданады. Мәселен,

Тәтей, айтқаныңызды ұқтым (Мұхаметқали 2008: 54).

Тәтей сөзі жасы үлкен әйел адамға ізет білдіру сыпайыгершілікпен айтылатын қаратпа сөз ретінде Қазақстанның оңтүстік аймақтарында қолданылады. Сонымен қатар, батыс өңірлерінде осы сөздің баламасы ретінде апай қолданылады. Бұндай қолданыстар жас жазушылардың шығармаларында көптеп кездеседі.

Мысалы, Лира Қоныстың «Бес тиын» шығармасында

Оны көктемге салым бөгде тәтей келіп алыс-алыс жақтағы балалар үйіне алып кеткен (Жаңа ғасыр әдебиеті 2015: 89)

Жозы - ұйғыр тілінен ауысқан, аласа үстел деген мағынаны білдіреді. Мысалы: Отырған қыз орнын табат та, оған несіне қиналдың! - деп Сарқыт оймақтай сырлы ожау мен екі тостағанды дем алатын бөлмедегі жозыға қойып қайта шықты (Қалиев 1989: 81).

Жозы сөзі көбінесе Алматы облысы Райымбек ауданының тұрғындары қолданады. Жозы сөзін Б.Сарыбайдың шығармасынан кездестіреміз. Жозының әдеби тілдегі баламасы - үстел, ас үстелі.

Жергілікті тіл ерекшеліктерінің эстетикалық мәні контекстегі қолданысы мен ішкі уәжділігі негізінде айқындалады. Шығармада жергілікті тіл ерекшеліктерінің қолданылуы белгілі бір аймақтың колоритін, шығарманың шынайылығын береді. Ол, ең алдымен, шығарманың тақы- рыбына, мазмұнына, суреттелетін оқиғаларға, автордың мақсатына, эстетикалық идеалы мен шеберлігіне байланысты. Алайда әдеби тілде жергілікті ерекшеліктерді шамадан тыс қолдану да шығарманың тілін шұбарландырып, түсініксіздікке ұрындырары сөзсіз (Сыздық 2005:151). Осыған орай, академик Р. Сыздық: «Түсініксіз болатын сөздер - белгілі бір аймақта ғана жұмсалатын жергілікті сөздер, олардың ішінде диалектизмдер мен жергілікті кәсіби сөздер, көне немесе сирек қолданылатын сөздер және жазушының өзі ұсынған жаңа қолданыстар. Демек, лексикалық норма проблемасының бір ұшы - көркем шығарма тілінде диалектизмдердің көрінісіне барып тіреледі.

Ғалым Р.Сыздық былай деп тұжырым жасайды: «Сөз жоқ, жалпы көпшілікке ортақ емес, қолдану аясы шектеулі сөздер мен тұлға-тәсілдерді ешбір себепсіз тоғытып жұмсау принципінде әдеби нормаға, оның ішінде ұлттық көркем сөз нормасына қайшы екендігі даусыз, бірақ текстіге бейтаныс элементтердің қолданылу себептерін, уәждіуәжсіздігін, қажеттілік дәрежесін, лексика қазынасын байыту мүмкіндігін т.т. жанжақты түгел есепке алған күнде ғана «иісі» диалектизмнен қашудың жөн еместігі және әңгіменің бір ұшы жазушы шеберлігіне (автор идеясына қызмет еттіре білу сипатына) 
тікелей қатысты екендігі байқалады. Демек, бұл жерде норма проблемасы стилистика мәселелерімен ұштастырыла қаралуға тиіс. Көркем әдебиет тілінде диалектизмдердің, кәсіби сөздердің немесе басқа да тосын қолданыстардың орын алуын сөз еткенде, оларды әрдайым нормадан ауытқу, тіл мәдениетін бұзу деп тануға болмайды. Бүгінгі қазақ көркем сөзінің тіл мәдениетін сақтау дегенде, біздіңше, ең алдымен сөзді дәл қолданбау, яғни сөзді орнымен дұрыс жұмсай алмау, қажетсіз кірме сөздерді енгізу, әдеби норма сыртында тұрған элементтерді ешбір зәруліксіз текстіге енгізуді айту керек» (Сыздық 2005:246).

Жоғарыда айтылғандарға сай, қазіргі жас жазушыларымыздың шығармаларынан да кейбір уәжсіз қолданылған диалектілерді кездестіреміз. Мәселен, Мирас Мұқаштың «Ақ шағала» жинағында:

Бәрібір жалықпайды. Қынбайды. Шәбелеп қайта шығады қарсы алаңға (Жаңа ғасыр әдебиеті 2015: 141).

Қас қарая төңіректегі қалың тал-шілік арасына сіңіп, мезгіл-мезгіл тым-тырыс жоқ болып кететіндері бар (Жаңа ғасыр әдебиеті 2015: 144).

Жуынып тұрып ажырайып айнаға қараса, екі көзі қып-қызыл, басы мыңғыдыңғы. (Жаңа ғасыр әдебиеті 2015: 135).

Дәлізге беттегенде бірін-бірі қаға-маға, сүріне-мүріне жүгірген студенттерді көрді (Жаңа ғасыр әдебиеті 2015: 145).

Мирас Мұқаштың пайдалануындағы шәбелеп, тал-шілік, мыңғы-дыңғы, қаға-маға сөздерінің барлығының әдеби тілде баламасы бар. Мәселен, шәбелеп шәуілдеп, тал-

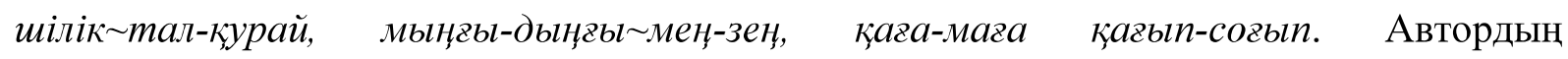
қолданысындағы диалектілер ешқайсысы автордың позициясына айқындап немесе қандай да бір мақсатта жұмсалып тұрған жоқ, керісінше шығарма мәтінін шұбарлап тұр.

Сонымен қатар жоғарыда берілген Мирас Мұқаштың сөзінде қынбайды деген диалект сөз қолданылған. Қынбайды сөзінің мағынасы диалектілік сөздікте келесідей берілген:

\section{ҚЫНБАУ}

(Қ.орда, Арал) беті қайтпау. Жауынгерлер қ ы н б а д ы, қайта олар өшіге түскендей (Ә. Нұрп., Курл., 7) (Диалектологиялық сөздік 2007: 525).

Осы секілді диалектілерді уәжсіз қолдануды Ж.Шағатай мен Д.Нәутәйұлының шығармаларынан да кездестіреміз.

Желбуаз пенде атаулының бір күндік жарық, жалт етіп сусыған сәулеге мәз болып күн кешуі де, тіпті барша өмірі де мән-мағынасыз нәсте, адамның қуанышқайғысы, әлденеге ұмтылысы мен әлсіз талпыныстары түгелімен жалған, кешкі мұнардай алдамшы көзбояу ғана (Шағатай 2008:51). 
Дүниенің барша жұмбағын шешсе де, мұқым адамзат әйел жанының құпияларын толық ашуға қабілетсіз (Шағатай 2008: 54).

Сол ыңғайсыз күйді мен де бір пәсте басымнан кештім (Жаңа ғасыр әдебиеті 2015: 89).

Жоғарыда берілген үзінділердегі нәсте, мұқым, пәсте диалектілік қолданыстары үәжсіз пайдаланылып тұр деп есептейміз. Бұл сөздердің барлығының әдеби тілде баламасы бар.

Бұл жердегі желбуаз сөзіне аймақтық сөздікте келесі мағына берілген:

\section{ЖЕЛБУАЗ}

1) (Гур., Маңғ.) буаз деп жүріп қысыр шығу..

2) (Қост., Жанг.) бос, құры. Шырағым, ж е л б у а з сөзіңді қойып жұмысыңды істеші (Қост., Жанг.) (Диалектологиялық сөздік 2007: 284).

Автор желбуаз сөзін пенде деген сөзге экспресивтік мән үстеу үшін қолданған. Бұл сөздің орнына бос жүрген пенде немесе бейқам, ешнәрсені ойламайтын, бір күндік өмір сүретін пенде деп қолданса, бұл сөз тіркестері авторлық прозицияны белгілі бір деңгейде жеткізе алмас еді.

Жоғарыдағы мұқым сөзі Қазақстанның түрлі аймақтарында әртүрлі мағынада қолданылады:

\section{МҰҚЫМ}

1) (Алм.: Шел., Кег.) тіпті, мүлде, ешбір. Болат кітапты м ұ қ ы м жатқа айтады (Алм., Кег.). - Алда разы болсын, көп жаса! Мұқтаж болып отыр ек, м ұ қ ы м (Ж. Нәжім., Кішк., 7). Аңшылар м ұ қ ы м тау ешкісінің өзіндей-ақ шапшаңдықпен, әлі өрлеп барады (Ғ. Сл., Кең өр., 8).

2) (Сем.: Ақс., Көкп., Абай; Тау., Қош.; Шығ. Қаз., Больш.; МХР) бүкіл, барлық. Мұқым бір ел мың қойды баға алмай отыр (Сем., Ақс.). Абайдың өліміне м ұ қ ы м ел болып қайғырдық (Сем., Абай).М ұ қ ы м бір тайпа елді чақырып той істеді (МХР). Бұқым түрінде де айтылады. Тарбағатай тауының күншығысынан ыңырана көтерілген ай м ұ қ ы м әлемді ақ сүт сәулеге орады (О. Бөк., Өз от. өш., ).

3) (Ақт., Ырғ.) бекем, берік, мығым. Қарағым, жол жүргенде нәрсеңе м ұ қ ы м бол (Ақт., Ырғ.).

4) (Гур., Маңғ.) тегі. Мен әншейін ойнасам о не не дегені, м ұ қ ы м (Гур., Маңғ.). Осы жұрт сол жалғыз атты жолаушыдан неге қорықты? Сонша дүрлігіп, м ұ қ ы м, сірə! (Ж. Нәжім., Кішк) (Диалектологиялық сөздік 2007: 485).

Осының ішінде автор мұқым сөзі бүкіл, барлық деген мағынада қолданып тұр.

Жас жазушылардың шығармаларын талдау барысында диалекті сөздерді автордың көздеген мақсатын жеткізу, белгілі бір мағына үстеу үшін қолданылатын жағдайларды көптеп кездестіруге болады. Мәселен, 
Онсыз да сұрқай қаладағы талғамсыздықтың ең сорақы үлгісі секілді, үш қабатты болса да келушілердің еңсесін езгендей, мейілінше жер бауырлап, жатағанданып көрінетін кеспірсіз, сұрқай ғимараттың неліктен балалардың еншісіне тигені де ешкім түсінбейтін жұмбақ (Сарыбай 2009: 73).

Осы үзіндідегі кеспірсіз сөзі аймақтық сөздікте келесідей мағынаны білдіреді.

\section{KECПIP}

1) (Гур., Маңғ.; Түрікм., Таш.) түр, әлпет, кескін, сиық. К е с п і р і жаман адамнан жақсылық шыға бермес болар (Гур., Маңғ.). Мынадай к е с п і р і нашар затты алар ма адам (Түрікм., Таш.). Осы сәтте Рақымбайдың көз алдына өзі қуған әлгі ақсақ немістің к е с п і р і келді (С. Сейіт., Сөз., 8) (Диалектологиялық сөздік 2007: 600).

Жоғарыдай айтқынымыздай бұл сөз авторлық мақсатқа жету үшін қолданылып тұр. Мәселен, кескінсіз сұрсыз түрі нашар кеспірсіз деген қатарда кеспірсіз сөзінің экспресивтілік мәні басқаларға қарағанда жоғары болып, ғимараттың сырт келбетінің тым нашар екендігін білдіріп тұр.

Әйтеуір міхірсіз тірліктің күйбеңі мен таусылмайтын қам-қарекеті шашыраңқы жүздеріне абыржу мен лажсыздықтың мөрін әбден тереңдеп, мүлдем өшпестей етіп басқан жұрттан ерекшелеп менмұндадалайды (Шағатай 2008: 65)

\section{MIГIP}

1) (Орал, Орда; Гур.: Есб., Маңғ.) маза, тыным. Ол бір м і г і р і жоқ адам (Орал, Орда). Ол м і г і р етпестен жұмыс жасады (Гур., Есб.). Оларда еш м і г і р жоқ (Қ. Жұмал., Айқас, ). Не де болса хан аулының о шеті мен бұ шетінде күні-түні м і г і р жоқ, абыр-сабыр (Ә. Кекіл., Үркер, 6) (Диалектологиялық сөздік 2007: 501).

Осының алдында берілген мысалдағыдай, міхірсіз тірлік қолданысының басқа тынымсыз тірлік мазасыз тірлік қолданыстарына қарағанда мағынасы қанығырақ, күйбеңі мен таусылмайтын қам-қарекеті көп, өмірі шаруасы бітпейтін тірлік деген мағынада қолданылып тұр.

Сонымен қатар, жас ақын-жазушылар диалектизмдерді кейіпкер ерекшелігі мен болмысын аша түсу үшін, өзіндік ерекшілігін таныту мақсатында қолданылады.

Кейіпкер образын жандандыра түсу тәсілдерінің бірі - оның тілінде сол өңірдің жергілікті ерекшеліктерін беру. Әрбір субъектінің жасына, қызметіне, өмір сүрген ортасына, күнделікті тіршілігіне қарай сөз қолданысы да басқалардан ерекшеленетіні белгілі. Олай болса, жазушы образ сомдауда осы ерекшеліктерді мүмкіндігінше мол қамтуға тырысып, экстралингвистикалық факторларды ескеріледі.

1 Талжан, бәрі де бітті. Енді кеш болып тұр... Енді телефон соғуың артық... Мен сөйлесе алмаймын.. Түсінсейш?, - деп телефон құлағын қоя салды (Алтай 1998: 49).

2 Қайымдікі құда шақырайын деп жатыр екен (Сарыбай 2009: 85).

Күтпеген сәтте уыз сезімге мелдектей толған жүрегім, әлденеге май ішкендей кілкіп, кеудемнен ұшып кетердей өрекпи соқты (Сарыбай 2009: 121). 


\section{МЕЛДЕК}

(Жамб.: Шу, Луг.) тойып тұру, тою. Су ішіп тұрған ғой деймін, мелдігі атып тұр ғой (Жамб.,Луг.) (Диалектологиялық сөздік 2007: 452).

Бұл мысалдарда берілген жүдә, нәйеті, әйбат, түсінсейш, қайымдікі (қайнымдікі), мелдек диалектілік қолданыстары кейіпкердің жергілікті ерекшеліктерін беру үшін қолданылған.

Қорыта айтқанда, көркем шығарма тілінде жазушы сол диалектілік аймақтан шыққандықтан сөз таңдауда жастайынан сіңген сөзді алады. Ұлттық әдеби тілдің тарих қойнауында жатқан диалектілердің өзіне тән ерекшеліктерін дұрыс ажырату бүгінгі ұлттық тіл мәдениетін көтеруге де үлкен ықпал етеді. Еліміз егемендік алғаннан бері қазақ тілінің қоғамдық қызметі жанданған уақытта көптеген диалектілерді қайтадан тілдік айналымға еніп, ұлттық тілдің сөздік қорын байытты, көптеген диалектілер терминдік сипат алып, ұлттық терминжасамның кәдесіне асты. Диалектілердің сөйленіс тіліндегі орфоэпиялық ерекшеліктерін сақтау тілдік норманы қалыптастырады.

Диалектизмдерді халықтың өткен тарихымен, әр аймақты жайлаған халықтардың мәдени-шаруашылық ерекшеліктерімен және аралас-құралас отырған көрші елдердің өмірімен қабыстыра отырып қарастырған абзал.

\section{Пайдаланылған әдебиеттер}

Айтбайұлы, Өмірзақ-Әбдірахманов, Сауытбек және т.б. (2007). Диалектологиялық сөздік. Алматы: Арыс.

Алтай, Асқар (1998). Қыр мен қуала хикаялары: Повестер мен әнұгімелер. Алматы: Санат.

Сарыбай, Бейбіт (2009). Рауаваш ерте гүлдейді. Алматы: Жалын.

Тулеуов, Есімбек-Асқар, Азамат және т.б. (2015). Жаңа васыр әдебиеті. Алматы: Санат

Қалиев, Ғабдолла (1989). “Диалектілік неологизм сөздер туралы”. Жовары оқу орындарының профессорлары мен оқытушылары, аспиранттарының мақалалар жинавы. Алматы: Мектеп, Б: 121-126.

Қалмаханбет, Мұқамедқали (2008). Гүл. Алматы: Санат.

Сарыбаев, Шора-Қалиев, Ғабдолла (2004). Қазақ диалектологиясы. Алматы: Арыс.

Сыздық, Рабиға (2005). Сөз құдіреті. Алматы: Атамұра.

Уәлиев, Нұргелді (2007). Диалектизмдер құбыжық емес. Алматы: Айқын.

Шағатай, Жаңабек (2008). Қандаваштың шоқ сырzасы: хикаяттар, әңгімелер. Алматы: Жазушы. 


\section{References}

Aitbaiuly, Omirzaq-Abdrahmanov, Sauytbek e.a. (2007). Dialektologiialık sozdik. Almaty: Arys.

Altai, Asqar (1998). Qyr men qala hikaialary: Povester men angimeler. Almaty: Sanat.

Beibit, Sarybai (2009). Rayagas erte guldeidi. Almaty: Jalyn.

Esimbek Tyleyov-Asqar, Azamat e.a. (2015). Jana gasyr adebieti. Almaty: Sanat

Qaliev, Gabdolla (1989). "Dialektilik neologizm sozder tyraly". Jogary oqy oryndarynyn professorlary men oqytysylary, aspiranttarynyn maqalalar jinagy. Pp: 121-126.

Qalmahanbet, Myqametqali (2008). Gul. Almaty: Sanat.

Sarybaev, Shora-Qaliev, Gabdolla (2004). Qazaq dialektologiiasy. Almaty: Arys.

Syzdyq, Rabiga (2005). Soz qudireti. Almaty: Atamura.

Yaliev, Nyrgeldi (2007). Dialektizmder qubyjyq emes. Almatı: Aiqyn.

Sagatai, Janabek (2008). Qandagastyn soq syrgasy: hikaiattar, angimeler. Almaty: Jazysy. 